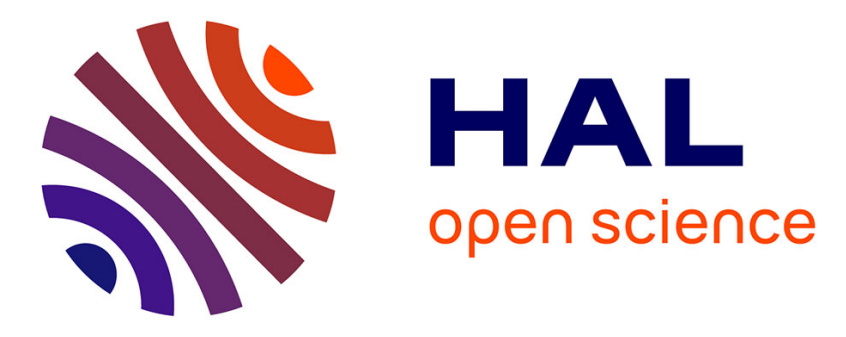

\title{
Impending effects of transpiration in blue light regulation of leaf growth
}

\author{
Didier Combes, Romain Barillot, Jean-Louis Durand, Abraham J. Escobar \\ Gutiérrez, Ela Frak
}

\section{- To cite this version:}

Didier Combes, Romain Barillot, Jean-Louis Durand, Abraham J. Escobar Gutiérrez, Ela Frak. Impending effects of transpiration in blue light regulation of leaf growth. Annual Meeting of the Societyfor-Experimental-Biology, Jun 2009, Glasgow, United Kingdom. 10.1016/j.cbpa.2009.04.467 . hal01594098

\section{HAL Id: hal-01594098 \\ https://hal.science/hal-01594098}

Submitted on 3 Jun 2020

HAL is a multi-disciplinary open access archive for the deposit and dissemination of scientific research documents, whether they are published or not. The documents may come from teaching and research institutions in France or abroad, or from public or private research centers.
L'archive ouverte pluridisciplinaire HAL, est destinée au dépôt et à la diffusion de documents scientifiques de niveau recherche, publiés ou non, émanant des établissements d'enseignement et de recherche français ou étrangers, des laboratoires publics ou privés. 


\section{Impending effects of transpiration in blue light regulation of leaf growth}

Didier Combes, Romain Barillot, Jean-Louis Durand, Abraham Escobar and Ela Frak

Light quality, drives several photomorphogenetic responses in plants such as leaf growth. A decrease in blue irradiance in the incident light leads to an increase in leaf elongation rate and final leaf length. The effects of blue light could be mediated by water flux into the growing zone since blue light has a direct effect on stomata aperture and consequently on plant transpiration. Indeed, several studies have demonstrated the effects of changes in transpiration rate on leaf elongation rate but little is known about the control of leaf elongation by water flux under low blue light conditions.

The objective of this study was to determine the contribution of plant transpiration for blue light control of leaf elongation. Plants of tall fescue were submitted to neutral or to blue lacking light treatment. Leaf elongation was measured before and after changes in light conditions by using LVDT- sensors. Plant transpiration was monitored continuously by the gravimetric method (balance).

In response to lack of blue light, leaf elongation rate was increased by about $11 \%$, conversely, transpiration rate and stomatal conductance were decreased by $25 \%$ and $33 \%$, respectively. These inverse changes in leaf elongation and plant transpiration exhibit a specific time-response pattern, were not observed in control plants. These results suggest that the effects of blue light on leaf growth in grasses are mediated by the effects of blue light on transpiration. 